\title{
The dose-dependent neuroprotective effect of alpha-lipoic acid in experimental spinal cord injury
}

\section{Zależne od dawki neuroprotekcyjne działanie kwasu alfa-liponowego w eksperymentalnym uszkodzeniu rdzenia kręgowego}

Murat Sayın', Peyker Temiz'2, Ahmet Var ${ }^{3}$, Cüneyt Temiz'

'Department of Neurosurgery, Celal Bayar University Medical Faculty, Manisa, Turkey

2Department of Pathology, Celal Bayar University Medical Faculty, Manisa, Turkey

${ }^{3}$ Department of Biochemistry, Celal Bayar University Medical Faculty, Manisa, Turkey

Neurologia i Neurochirurgia Polska 2013; 47, 4: 345-351

DOI: 10.5114/ninp.2013.36207

\begin{abstract}
Background and purpose: Free radical production after spinal cord injury (SCI) plays an important role in secondary damage. The aim of this study was to investigate neuroprotective effects of the powerful antioxidant alpha-lipoic acid (ALA) in a spinal cord clip compression injury model.

Material and methods: Fifty-six Sprague-Dawley rats, weighing between 210 and $300 \mathrm{~g}$, were randomly divided into seven groups. Spinal cord injury was performed by an aneurysm clip placed extradurally at the level of T9. Group 1 (sham) received laminectomy only. Group 2 (control) received SCI; Group 3 received $30 \mathrm{mg} / \mathrm{kg}$ of methylprednisolone sodium succinate (MPSS); Groups 4, 5, 6 and 7 received ALA at doses of $50,100,150,200 \mathrm{mg} / \mathrm{kg}$, respectively, via the intraperitoneal route immediately after SCI. The rats were neurologically tested 24 hours after trauma. Spinal cord samples from injury sites were harvested for measurement of lipid peroxidation products and histopathological evaluation.

Results: Spinal cord malonyldialdehyde levels of rats in treatment groups decreased after administration of ALA. The difference between the trauma group and groups receiving MPSS-ALA was statistically significant. The difference between the ALA $(50,100,150 \mathrm{mg} / \mathrm{kg})$ and MPSS groups was insignificant. Group 7 (ALA $200 \mathrm{mg} / \mathrm{kg}$ ) was excluded
\end{abstract}

\section{Streszczenie}

Wstęp i cel pracy: Powstawanie wolnych rodników po urazowym uszkodzeniu rdzenia kręgowego (UURK) odgrywa istotną rolę w jego wtórnym uszkodzeniu. Celem badania było sprawdzenie neuroprotekcyjnego działania silnego antyoksydantu, kwasu alfa-liponowego (ALA), w eksperymentalnym modelu uszkodzenia rdzenia kręgowego wywoływanego uciskiem przez klips.

Materiał i metody: Pięćdziesiąt sześć szczurów rasy Sprague-Dawley o masie 210-300 g podzielono na 7 grup. Uraz rdzenia kręgowego wywoływano przez założenie klipsa zewnątrztwardówkowo na poziomie Th9. W grupie 1. (procedura pozorowana) wykonano jedynie laminektomię, w grupie 2 . (kontrolnej) wykonano UURK. W grupie 3. podano bursztynian sodowy metyloprednizolonu (MPSS) w dawce $30 \mathrm{mg} /$ $\mathrm{kg}$ m.c. W grupach 4.-7. po UURK podano ALA w dawkach odpowiednio 50, 100, 150 i $200 \mathrm{mg} / \mathrm{kg}$ m.c. dootrzewnowo bezpośrednio po UURK. Szczury badano neurologicznie po 24 godzinach od urazu. Próbki rdzenia kręgowego $\mathrm{z}$ miejsc uszkodzenia pobrano w celu oceny produktów peroksydacji lipidów i do badania histopatologicznego.

Wyniki: Stężenia malonylodialdehydu u szczurów poddanych leczeniu zmniejszyły się w grupach, w których stosowano ALA. Różnica między grupą kontrolną a grupami otrzy-

Correspondence address: Murat Sayın, MD, Celal Bayar University Medical Faculty, Department of Neurosurgery, phone: + 905052531310, e-mail:drmuratsayin@yahoo.com

Received: 30.05.2012; accepted: 8.11.2012 
from the study because of the possible toxic effect. Alpha lipoic acid and MPSS had similar effects on spinal cord injury in terms of lipid peroxidation, neurological recovery and histopathological changes.

Conclusions: Alpha lipoic acid at a dose range of 50-150 mg/ $\mathrm{kg}$ is as effective as MPSS (30 mg/kg) in neuroprotection after SCI. Further, more detailed experimental studies are needed to determine the effects of ALA on the detrimental results of secondary SCI before its use in humans.

Key words: spinal cord injury, alpha-lipoic acid, free radical, lipid peroxidation, methylprednisolone.

\section{Introduction}

A lot of research has focused on pathophysiology of acute spinal cord injury (SCI) to find methods to restore neurological function. Acute injury involves two different, interrelated mechanisms of damage to the spinal cord: primary mechanical injury and a subsequent secondary injury because of additional damage after the initial injury [1]. The main autodestructive processes are secondary ischaemic changes, free radical formation, and free radical-induced lipid peroxidation with damage of lipid membranes in the spinal cord [2]. The exact mechanism is unknown, but many pathological changes, including edema, inflammation, altered blood flow, and changes in microvascular permeability, may contribute to the development of secondary injury by various pathways that include free oxygen radicals and lipid peroxidation [3-6]. Among these mechanisms, secondary injury draws much attention because of its nature, being susceptible to pharmacological intervention. Therefore, many studies have focused on neuroprotective agents against secondary injury [3-9].

Free radical production after SCI plays an important role in secondary injury [10-12]. Alpha-tocopherol, selenium, naloxone, and methylprednisolone sodium succinate (MPSS) are powerful antioxidants when given in large doses, and they effectively reduce posttraumatic neurological deficits [10-12]. According to a Cochrane Review [5], after spinal cord trauma 'high-dose methylprednisolone steroid therapy is the only pharma- mującymi MPSS-ALA była istotna statystycznie. Różnice między grupami, w których podawano ALA w dawce 50, 100 i $150 \mathrm{mg} / \mathrm{kg}$ m.c., a grupą, w której zastosowano MPSS, nie była istotna. Grupę 7. (ALA w dawce $200 \mathrm{mg} / \mathrm{kg}$ ) wyłączono z analizy ze względu na możliwe toksyczne działanie ALA. Kwas alfa-liponowy i MPSS wywierały zbliżony wpływ na uszkodzenie rdzenia kręgowego oceniane za pomocą peroksydacji lipidów, poprawy stanu neurologicznego i zmian histopatologicznych.

Wnioski: Skuteczność ALA w dawkach 50-150 mg/kg m.c. w neuroprotekcji po urazie rdzenia kręgowego jest taka sama jak skuteczność MPSS (30 mg/kg m.c.). Konieczne są dalsze, bardziej szczegółowe badania eksperymentalne w celu określenia wpływu ALA na niekorzystne następstwa uszkodzeń wtórnych po UURK przed zastosowaniem ALA u ludzi.

Słowa kluczowe: urazowe uszkodzenie rdzenia kręgowego, kwas alfa-liponowy, wolne rodniki, peroksydacja lipidów, metyloprednizolon.

cological therapy shown to have efficacy when it can be administered within 8 hours of injury'. It is known that alpha-lipoic acid (ALA) is a powerful lipophilic antioxidant in vitro and in vivo [13]. Alpha-lipoic acid is an important co-factor for several mitochondrial dehydrogenases and, along with its reduced form, dihydrolipoic acid (DHLA), participates in redox reactions involved with acyl group transfers [14].

Despite recent improvements in surgical techniques, currently there is no efficacious therapy for SCI. An ideal treatment for secondary SCI would be one administered systemically without significant side effects. One currently untested therapeutic agent is ALA, which has been shown by some authors to possess potent neuroprotective properties in experimental cerebral ischaemia and reperfusion injury in peripheral nerves $[14,15]$.

The aim of this study was to investigate neuroprotective effects of the powerful antioxidant ALA in a spinal cord clip compression injury model.

\section{Material and methods}

\section{Description of groups}

Fifty-six adult female Sprague-Dawley rats weighing 210-300 g were used for the study. Animals were housed under standard conditions in the Animal Research Laboratory at Celal Bayar University. Twelvehour daylight and darkness cycles were normally applied before and after surgery. Room temperature was kept 
constant. The study protocol was approved by the Animal Research and Ethics Committee of Dokuz Eylül University (200906). The rats were given free access to water and food. The rats were randomly and blindly divided into seven groups, each containing eight rats. In the control group (group 1), total laminectomies were performed and non-traumatized spinal cord samples were obtained immediately. In the trauma group (group 2), total laminectomies were performed and spinal cord samples were removed at 24 hours after trauma. In the MPSS group (group 3), total laminectomies were performed, and animals were given a single dose of $30 \mathrm{mg} / \mathrm{kg}$ MPSS (Mustafa Nevzat, Istanbul, Turkey) intraperitoneally, immediately after trauma; spinal cord samples were obtained at 24 hours after trauma. In ALA groups (groups 4, 5, 6 and 7), total laminectomies were performed; animals were given a single dose of 50, 100, 150 or $200 \mathrm{mg} / \mathrm{kg}$ ALA, respectively (Thioctacid $600 \mathrm{~T}$ Injectable, Meda Pharma, Germany) intraperitoneally immediately after trauma and spinal cord samples were obtained at 24 hours after trauma.

\section{Surgical procedures}

All rats were anesthetized via bolus intraperitoneal injection of sodium pentobarbital $(20 \mathrm{mg} / \mathrm{kg}$ ) (Bayer Turk Company, Istanbul, Turkey). Rats were positioned prone on the operating table. A midline dorsal incision was done with sterile technique. The laminae and transverse processes of T9-T12 were exposed by gentle blunt dissection of paravertebral muscles. A self-retaining microretractor was placed in the operation area, and laminectomy was performed at T8-10. Strict bleeding control was maintained by using bone wax and a bipolar coagulator. An aneurysm clip (Yasargil FE751, closing pressure $30 \pm 2 \mathrm{~g}$ ) was applied extradurally for one minute on the thoracic spinal cord. Intraperitoneal MPSS or ALA was injected according to the group. After careful removal of the aneurysm clip, paravertebral fascia and skin were sutured separately with silk stitches. Complete closure of the surgical wound was achieved. Complicated cases, such as dural tearing or inadvertent spinal injuries, were excluded from the study.

\section{Sacrifice of animals and sample preparation}

Rats were killed by overdose of pentobarbital (200 mg/ $\mathrm{kg}$ ) after 24 hours. Spinal cords at the injury site were excised for a length of $2 \mathrm{~cm}: 1 \mathrm{~cm}$ rostrally and $1 \mathrm{~cm}$ caudally to the injury site. Tissue samples were immediate- ly stored in a $-20^{\circ} \mathrm{C}$ freezer for assays of malonyldialdehyde (MDA).

\section{Determination of lipid peroxidation in traumatized spinal cord tissue}

The levels of lipid peroxides in traumatized spinal cord tissue were measured as thiobarbituric acid-reactive material and determined using the method of Mihara and Uchiyama [14]. Malonyldialdehyde has been identified as the product of lipid peroxidation that reacts with thiobarbituric acid to give a red species absorbing at $535 \mathrm{~nm}$. The assay procedure for lipid peroxide in spinal cord tissue was set up as follows. Tissues were homogenized in 10 volumes (wt/vol) of cold $1.5 \%$ $\mathrm{KCl} ; 0.5 \mathrm{~mL}$ of homogenate was mixed with $3 \mathrm{~mL}$ of $1 \%$ of $\mathrm{H}_{3} \mathrm{PO}_{4}$ and $1 \mathrm{~mL}$ of $0.6 \%$ thiobarbituric acid. The mixture was then heated in boiling water for 60 minutes. After cooling, the color was extracted into $4 \mathrm{~mL} n$-butanol, and the absorbance was recorded at 535 and $520 \mathrm{~nm}$. Using tetramethoxypropane as the standard, tissue lipid peroxide levels were calculated as nanomoles per gram of wet tissue.

\section{Functional evaluation}

Functional evaluation of the rats was made 24 hours after trauma. Evaluation of maximum slope at which rats maintained themselves for 5 seconds was performed by the inclined plane technique of Rivlin and Tator [16]. Assessments of hind limb function during open field walking were performed by using the Basso, Beattie, and Bresnahan (BBB) scoring system as described previously [17]. Briefly, rats were gently adapted to the open field. Once a rat walked continuously in the open field, two examiners conducted a 4-minute testing session using the $\mathrm{BBB}$ locomotor rating scale [17]. The BBB scale rates were based on different levels of movements of the hind limbs, with 21 points being the maximum score. This test mainly evaluates the movement of joints, weight support and plantar placement of the paw, weight-supported plantar steps, and fore limb-hind limb coordination. Average BBB scores of both legs were used. The evaluations were performed in a blinded fashion.

\section{Light microscopic evaluation}

Two millimeters of cross-sectional gray and white matter at the epicenter of the spinal cord lesion was removed for microscopic examination. The sections were 
stained with hematoxylin-eosin (HE) and modified Gomori trichrome (MGT). The investigator evaluating the sections was blinded to the group information.

\section{Statistical analyses}

All data were obtained and originally analyzed using SPSS 13.0 for Windows (SPSS Inc., Chicago, IL, USA), by researchers who were blinded to the treatments the rats had received. Comparison among groups was done with Kruskal-Wallis analysis of variance and the Mann-Whitney $U$-test. Results are expressed as mean \pm standard

Table 1. Mean Baso, Beattie, and Bresnahan scores among the studied groups*

\begin{tabular}{|lc|}
\hline Group & Score \\
\hline Control & $21.0 \pm 0$ \\
\hline Trauma & $0.2 \pm 0.4$ \\
\hline Methylprednisolone sodium succinate & $7.0 \pm 4.48$ \\
\hline Alpha-lipoic acid $(50 \mathrm{mg} / \mathrm{kg})$ & $9.6 \pm 6.4$ \\
\hline Alpha-lipoic acid $(100 \mathrm{mg} / \mathrm{kg})$ & $10.4 \pm 5.7$ \\
\hline Alpha-lipoic acid $(150 \mathrm{mg} / \mathrm{kg})$ & $8.4 \pm 6.2$ \\
\hline *Data are expressed as means \pm standard deviations.
\end{tabular}

Table 2. Mean inclined plane degrees among the studied groups*

\begin{tabular}{|lc|}
\hline Group & Plane $\left(^{\circ}\right)$ \\
\hline Control & $82.0 \pm 3.42$ \\
\hline Trauma & $40.0 \pm 10.16$ \\
\hline Methylprednisolone sodium succinate & $60.0 \pm 7.32$ \\
\hline Alpha-lipoic acid $(50 \mathrm{mg} / \mathrm{kg})$ & $63.23 \pm 12.35$ \\
\hline Alpha-lipoic acid $(100 \mathrm{mg} / \mathrm{kg})$ & $68.1 \pm 8.25$ \\
\hline Alpha-lipoic acid $(150 \mathrm{mg} / \mathrm{kg})$ & $59.56 \pm 10.4$ \\
\hline *Data are expressed as means \pm standard deviations. &
\end{tabular}

Table 3. Changes in spinal cord tissue lipid peroxidation levels among studied groups as measured by malonyldialdehyde levels*

\begin{tabular}{|lc|}
\hline Group & $\begin{array}{c}\text { Malonyldialdehyde } \\
\text { level (nmol/g } \\
\text { of wet tissue) }\end{array}$ \\
\hline Control & $62.0 \pm 10$ \\
\hline Trauma & $173.4 \pm 16$ \\
\hline Methylprednisolone sodium succinate & $114.0 \pm 13$ \\
\hline Alpha-lipoic acid $(50 \mathrm{mg} / \mathrm{kg})$ & $109.0 \pm 12$ \\
\hline Alpha-lipoic acid $(100 \mathrm{mg} / \mathrm{kg})$ & $105.6 \pm 14$ \\
\hline Alpha-lipoic acid $(150 \mathrm{mg} / \mathrm{kg})$ & $102.3 \pm 15$ \\
\hline *Data are expressed as means \pm standard deviations. & \\
\hline
\end{tabular}

deviation, median, and range. The differences were considered significant when $p$-values were less than 0.05 .

\section{Results}

\section{Inclined plate tests and BBB scores}

Group 7 (ALA $200 \mathrm{mg} / \mathrm{kg}$ ) was excluded from the study because of the possible toxic effect [18]. All rats in this group were dead at twelve hours after trauma and drug applications.

Inclined plane (IP) degree values showed statistically significant differences among groups. Trauma showed a statistically significant decrease in IP values $(p<0.05)$. Both MPSS and ALA groups were significantly different from the trauma group $(p<0.05)$. The difference between MPSS and ALA groups was not significant $(p>0.05)$. The comparison of ALA doses showed no significant difference (Table 1).

There was a statistically significant difference between the control and the trauma groups in the mean BBB scores $(p<0.05)$. Trauma was found to decrease BBB scores significantly $(p<0.05)$. The trauma group scores were significantly different from the MPSS or the ALA groups $(p<0.05)$. The comparison of ALA doses showed no significant difference (Table 2).

\section{MDA levels}

The MDA levels were highest in the trauma group and lower in the ALA and MPSS groups. Comparison of the MDA values of the groups with Kruskal-Wallis variance analysis revealed statistical significance $(p<0.05)$. When the groups were compared using post-hoc Mann-Whitney $U$-test, the results were as follows. When the trauma group was compared with the MPSS and ALA groups, the results were statistically significant $(p<0.05)$. The ALA treatment group demonstrated better results than the MPSS and the trauma groups numerically but showed no statistically significant difference between the MPSS group and the ALA group $(p>0.05)$. The comparison of ALA doses showed no significant difference (Table 3 ).

\section{Histopathological evaluation findings}

The control group demonstrated normal histological structures and it seems that trauma produced significant damage with prominent evidence of haemorrhage and cellular edema. The MPSS group showed 

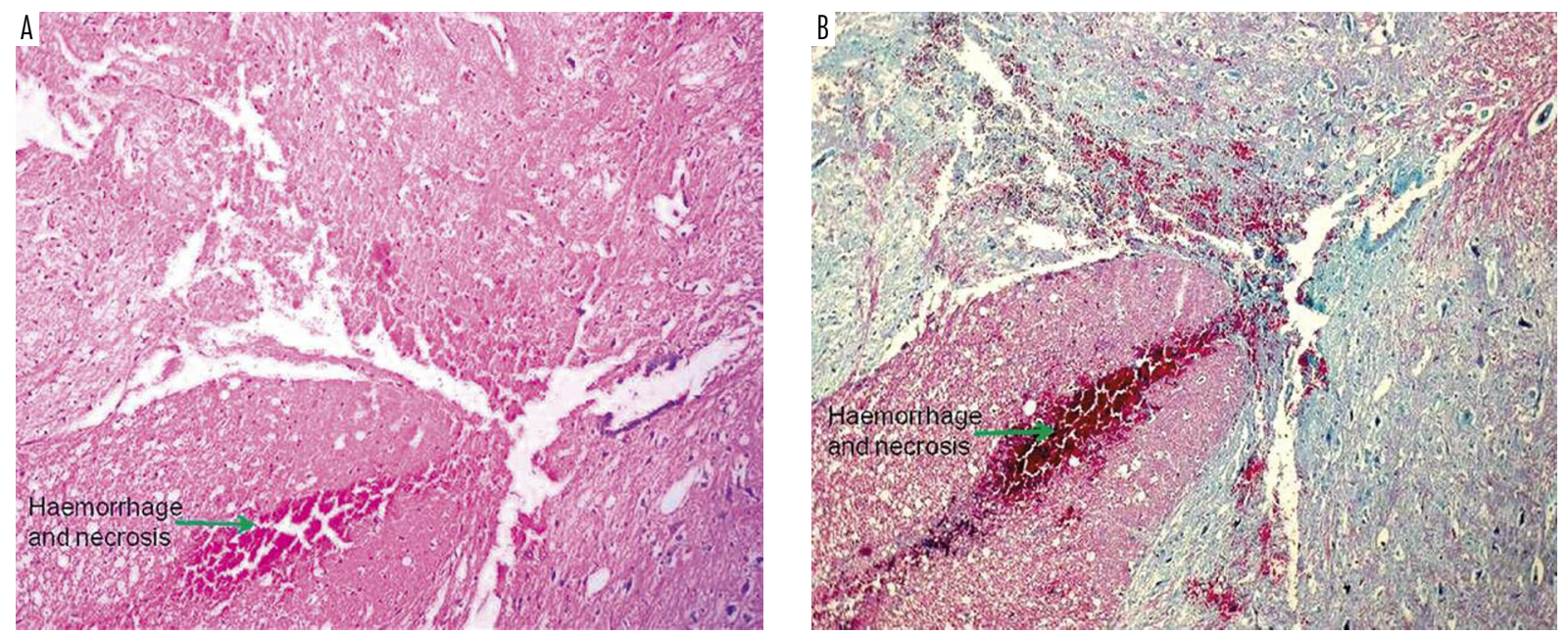

Fig. 1. Histological findings in trauma group included haemorrhage and necrosis
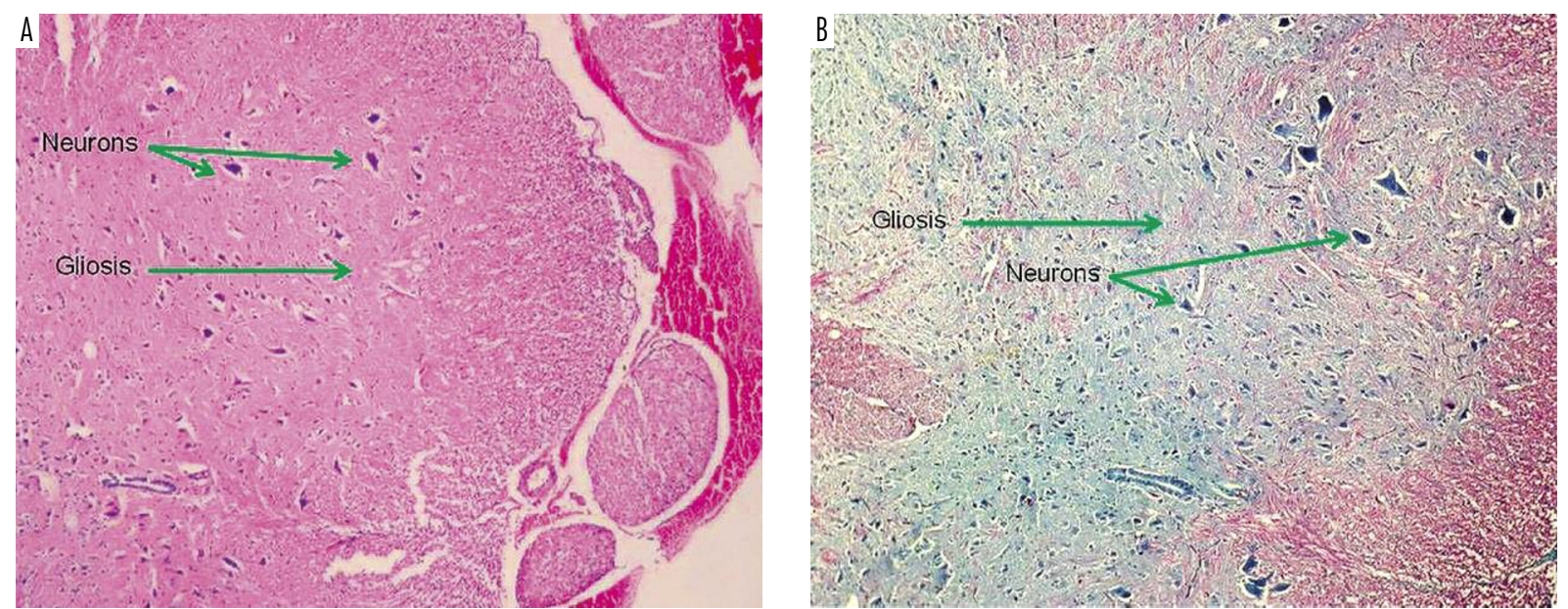

Fig. 2. Histological findings in the group treated with methylprednisolone sodium succinate showed gliosis and loss of neurons
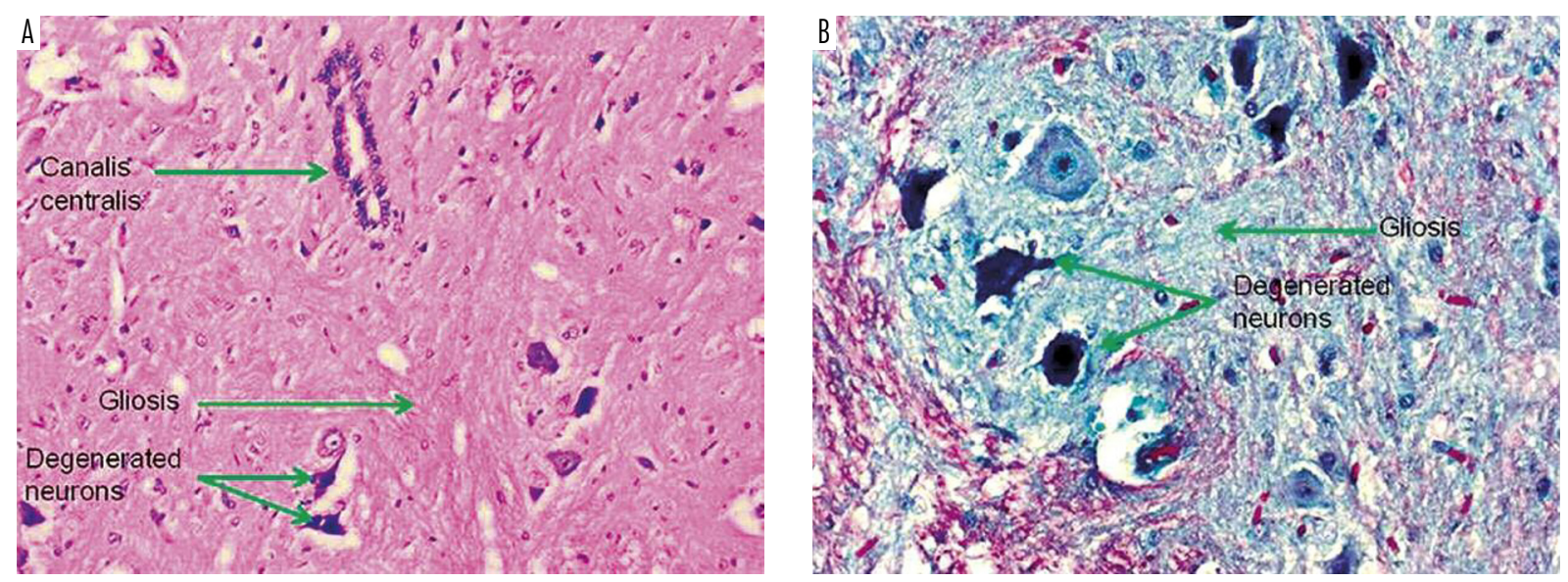

Fig. 3. Histological findings in the group treated with alpha-lipoic acid showed gliosis and degenerated neurons 
evidence of haemorrhage with minimal cellular edema. In the ALA-treated groups $(50,100$, and $150 \mathrm{mg} / \mathrm{kg})$ histopathological structures were very similar and there was no significant difference from the MPSS group. Histopathological findings are presented in Figs. 1-3.

\section{Discussion}

Damage following SCI can be categorized as primary neuronal damage from the trauma itself and secondary damage caused by a cascade of events. Secondary spinal cord injury has been extensively studied in detail in recent decades. Secondary injury is considered as a result of biochemical and pathological interactions at the cellular level that causes increase in some excitotoxic neuromediators, excessive calcium release, reactive oxygen species (ROS) and lipid peroxidation and resulting edema, haemorrhage and ischaemia. All of them can cause dysfunction and death in neuronal cells [19]. ROS-induced lipid peroxidation is one of the most important components precipitating posttraumatic neuronal degeneration in the SCI [19]. Reactive oxygen species react with lipids and cause peroxidative changes that result in elevated lipid peroxidation. The increase in lipid peroxidation may be related to decrease in enzymatic and nonenzymatic antioxidants of defense mechanisms. Due to high lipid content and high oxygenation, lipid peroxidation-related cellular damage might be easily formed by ROS [19].

Alpha-lipoic acid is especially promising as an antioxidant, acting against mitochondrial dysfunction, due to its mitochondrial alpha-ketoacid dehydrogenase complexes [13]. Thiols are central to antioxidant defense in nervous and other tissues. The most important thiol antioxidant, glutathione, cannot be directly administered, whereas ALA can. In vitro, animal and preliminary human studies indicate that ALA may be effective in preventing or treating numerous neurodegenerative disorders with this effect [13]. A review of current research reveals protective effects of ALA in cerebral ischaemiareperfusion, excitotoxic amino acid brain injury, mitochondrial dysfunction, diabetic neuropathy, inborn errors of metabolism, and other causes of acute or chronic damage to brain or neural tissue [13]. Demopoulos et al. [20] showed that the protective effect of methylprednisolone depends on its scavenging effects on free radicals more than its anti-inflammatory and immunosuppressive influences. Different studies showed that methylprednisolone has a strong limitation effect on lipid peroxidation, and it regulates microcirculation and cel- lular recovery with higher doses [9]. These results suggest that methylprednisolone may act through different mechanisms unrelated to corticosteroid receptors. The dose range of this beneficial effect is observed only at $30 \mathrm{mg} / \mathrm{kg}$ both in animal and clinical studies [21].

We aimed to investigate a currently untested therapeutic agent, the powerful antioxidant ALA, which has been shown by some authors to possess potent neuroprotective properties $[14,15]$, in a spinal cord clip compression injury model.

The results of our study demonstrated that spinal cord MDA levels of rats in the treatment groups decreased after administration of ALA at a dose range of $50-150 \mathrm{mg} / \mathrm{kg}$. The difference between the trauma and MPSS and ALA groups was statistically significant. The difference between the ALA doses and steroid groups was insignificant; this can be interpreted as ALA and MPSS having similar effects on spinal cord injury, in terms of lipid peroxidation, neurological recovery or histopathological tissue changes. Future studies, showing electron microscopic and immunohistochemical effects of ALA on spinal cord injury and lower doses $(<50 \mathrm{mg} / \mathrm{kg}$ ) of ALA, should be planned to assess whether ALA also provides long-term neuroprotection after SCI.

Therefore, more and detailed experimental studies are needed to determine the effects of ALA on the detrimental results of secondary SCI, including lower dose applications.

\section{Conclusions}

Alpha-lipoic acid at a dose range of $50-150 \mathrm{mg} / \mathrm{kg}$ is as effective as MPSS (30 mg/kg) in neuroprotection after SCI.

\section{Disclosure}

Authors report no conflict of interest.

\section{References}

1. Tator C.H. Biology of neurological recovery and functional restoration after spinal cord injury. Neurosurgery 1998; 42: 696-707.

2. Tator C.H., Fehlings M.G. Review of the secondary injury theory of acute spinal cord trauma with emphasis on vascular mechanisms. J Neurosurg 1991; 75: 15-26.

3. Anderson D.K., Dugan L.L., Means E.D., et al. Methylprednisolone and membrane properties of primary cultures of mouse spinal cord. Brain Res 1994; 637: 119-125. 
4. Hall E.D. Lipid peroxidants in acute central nervous system injury. Ann Emerg Med 1993; 22: 1022-1027.

5. Ildan F., Polat S., Oner A., et al. Effects of naloxone on sodium- and potassium-activated and magnesium-dependent adenosine- $5 \phi$-triphosphatase activity and lipidperoxidation and early ultrastructural findings after experimental spinal cord injury. Neurosurgery 1995; 36: 797-805.

6. Gezici A.R., Karakas A, Ergün R., et al. Serum cortisol levels following acute experimental spinal cord injury. Neurol Neurochir Pol 2009; 43: 352-357.

7. Wang H., Liu C., Ma X. Alginic acid sodium hydrogel cotransplantation with Schwann cells for rat spinal cord repair. Arch Med Sci 2012; 8: 563-568.

8. Kaptanoglu E., Beskonakli E., Solaroglu I., et al. Magnesium sulfate treatment in experimental spinal cord injury: emphasis on vascular changes and early clinical results. Neurosurg Rev 2003; 26: 283-287.

9. Means E.D., Anderson D.K., Waters T.R., et al. Effect of methylprednisolone in compression trauma to the feline spinal cord. J Neurosurg 1981; 55: 200-208.

10. Bracken M.B. Steroids for acute spinal cord injury. Cochrane Database Syst Rev 2002; CD001046.

11. Braughler J.M., Hall E.D. Correlation of methylprednisolone levels in cat spinal cord with its effects on $(\mathrm{Na} 2+\mathrm{K}+)$ ATPase lipid peroxidation, and alpha motor neuron function. $J$ Neurosurg 1982; 56: 838-844.

12. Saunders R.D., Dugan L.L., Demediuk P., et al. Effects of methylprednisolone and the combination of alpha-tocopherol and selenium on arachidonic acid metabolism and lipid peroxidation in traumatized spinal cord tissue. J Neurochem 1987; 49: 24-31.

13. Packer L., Witt E.H., Tritschler H.J. Alpha-lipoic acid as a biological antioxidant. Review. Free Rad Biol Med 1995; 19: 227-250.

14. Mihara M., Uchiyama M. Determination of malonaldehyde precursor in tissues by thiobarbituric acid test. Anal Biochem 1978; 86: 271-278.

15. Panigrahi M., Sadguna Y., Shivakumar B.R., et al. Alpha-lipoic acid protects against reperfusion injury following cerebral ischemia in rats. Brain Res 1996; 22: 184-188.

16. Rivlin A.S., Tator C.H. Effect of duration of acute spinal cord compression in a new acute cord injury model in the rat. Surg Neurol 1978; 10: 39-43.

17. Basso D.M., Beattie M.S., Bresnahan J.C. Graded histological and locomotor outcomes after spinal cord contusion using the NYU weight-drop device versus transection. Exp Neurol 1996; 139: 244-256.

18. Biewenga G.P., Haenen G.R., Bast A.The pharmacology of the antioxidant lipoic acid. Gen Pharmacol 1997; 29: 315-333.

19. Hall E.D., Wolf D.L. A pharmacological analysis of pathophysiological mechanisms of posttraumatic spinal cord ischemia. J Neurosurg 1986; 64: 951-956.

20. Demopoulos H.B., Flamm E.S., Pietonigro D.D., et al. The free radical pathology and the microcirculation in the major central nervous system disorders. Acta Physiol Scand 1980; 492: 91-119.

21. Bracken M.B., Shepard M.J., Collins W.F., et al. Methylprednisolone or naloxone treatment after acute spinal cord injury. Results of the second national acute spinal cord injury study. J Neurosurg 1992; 76: 23-31. 